\title{
The Cell Surface Receptors Ror1/2 Control Cardiac Myofibroblast Differentiation
}

Chavkin: Ror1/2 in Cardiac Myofibroblast Differentiation

Nicholas W. Chavkin Ph.D.* ${ }^{1,2}$, Soichi Sano M.D. Ph.D. ${ }^{1,3,4,5,6}$, Ying Wang M.D. Ph.D. ${ }^{1,3,4,7}$, Kosei Oshima M.D. Ph.D. ${ }^{4}$, Hayato Ogawa M.D. Ph.D. ${ }^{1,5}$, Keita Horitani M.D. ${ }^{1,5}$, Miho Sano M.D. Ph.D. ${ }^{1,4,5}$, Susan MacLauchlan Ph.D. ${ }^{4}$, Anders Nelson ${ }^{1,8}$, Karishma Setia ${ }^{1}$, Tanvi Vippa ${ }^{1}$, Yosuke Watanabe M.D. Ph.D. ${ }^{9}$, Jeffrey J. Saucerman Ph.D. ${ }^{1,10}$, Karen K. Hirschi Ph.D. ${ }^{1,2,3,11}$, Noyan Gokce M.D. ${ }^{12}$, Kenneth Walsh Ph.D. ${ }^{1,3,4,6}$

*Authors contributed equally to this work

${ }^{1}$ Cardiovascular Research Center, School of Medicine, University of Virginia

${ }^{2}$ Department of Cell Biology, School of Medicine, University of Virginia

${ }^{3}$ Hematovascular Biology Center, School of Medicine, University of Virginia

${ }^{4}$ Molecular Cardiology/Whitaker Cardiovascular Institute, Boston University School of Medicine, Boston, Massachusetts

${ }^{5}$ Department of Cardiology, Graduate School of Medicine, Osaka City University, Osaka, Japan

${ }^{6}$ Department of Cardiology, School of Medicine, University of Virginia

${ }^{7}$ Department of Cardiology, Xinqiao Hospital, Army Medical University, Chongqing, China

${ }^{8}$ Department of Pharmacology, University of Virginia

${ }^{9}$ Vascular Biology/Whitaker Cardiovascular Institute, Boston University School of Medicine, Boston, Massachusetts

${ }^{10}$ Department of Biomedical Engineering, University of Virginia

${ }^{11}$ Cardiovascular Research Center, School of Medicine, Yale University

${ }^{12}$ Boston University, School of Medicine, Boston, Massachusetts

Corresponding Author: Kenneth Walsh, Ph.D.

Email:kw9ar@virginia.edu

Address: University of Virginia School of Medicine

MR5 Building Room 1312

415 Lane Road

Charlottesville, Virginia 22908

Subject Terms: Cell Signalling/Signal Transduction, Fibrosis, Inflammation, Mechanisms, Heart Failure 


\section{Abstract}

Background: A hallmark of heart failure is cardiac fibrosis, which results from the injuryinduced differentiation response of resident fibroblasts to myofibroblasts that deposit extracellular matrix. During myofibroblast differentiation, fibroblasts progress through polarization stages of early pro-inflammation, intermediate proliferation, and late maturation, but the regulators of this progression are poorly understood. Planar cell polarity receptors, receptor tyrosine kinase like orphan receptor 1 and 2 (Ror1/2), can function to promote cell differentiation and transformation. In this study, we investigated the role of the Ror1/2 in a model of heart failure with emphasis on myofibroblast differentiation.

Methods and Results: The role of Ror1/2 during cardiac myofibroblast differentiation was studied in cell culture models of primary murine cardiac fibroblast activation and in knockout mouse models that underwent transverse aortic constriction (TAC) surgery to induce cardiac injury by pressure overload. Expression of Ror1 and Ror2 were robustly and exclusively induced in fibroblasts in hearts after TAC surgery, and both were rapidly upregulated after early activation of primary murine cardiac fibroblasts in culture. Cultured fibroblasts isolated from Ror1/2-KO mice displayed a pro-inflammatory phenotype indicative of impaired myofibroblast differentiation. Although the combined ablation of Ror1/2 in mice did not result in a detectable baseline phenotype, TAC surgery led to the death of all mice by day 6 that was associated with myocardial hyper-inflammation and vascular leakage.

Conclusions: Together, these results show that Ror $1 / 2$ are essential for the progression of myofibroblast differentiation and for the adaptive remodeling of the heart in response to pressure overload.

Key Words: Inflammation, Fibroblasts, Myocardial Inflammation, Fibrosis, Heart Failure 


\section{Non-standard Abbreviations and Acronyms}

Ror1/2 Receptor tyrosine kinase like orphan receptor 1 and 2

TAC Transverse Aortic Constriction

TGF- $\beta \quad$ Transforming Growth Factor Beta

Ptk7 Tyrosine-protein kinase-like 7 (Colon carcinoma kinase 4 (CCK4))

Prickle1 Prickle homologue 1

Vangl1/2 Vang-Like 1 and 2

Dvl1/2/3 Disheveled 1, 2, and 3

Ubc-Cre ${ }^{\text {ERT2 }}$ Ubiquitin C-driven Cre recombinase with tamoxifen-inducible mutant human estrogen receptor (ERT2)

LacZ Beta-galactosidase 


\section{Introduction}

Excessive fibrosis during pathological cardiac remodeling is a hallmark of heart failure and the response to cardiac injury. Cardiac fibrosis is the result of resident cardiac fibroblasts that undergo myofibroblast differentiation to promote inflammation and secrete extracellular matrix in response to various forms of cardiac injury ${ }^{1-4}$. Although injury-induced inflammation and matrix deposition is an adaptation to acute cardiac injury that can prevent the heart from rupture $^{5,6}$, excessive fibrotic deposition leads to ventricle stiffness that impairs cardiac function ${ }^{7-}$

89 . Recently, myofibroblast differentiation has been characterized as a transition through what is 9 referred to as three phenotypic polarization stages: an initial pro-inflammatory phenotype, an 10 intermediate proliferative phenotype, and a final mature phenotype ${ }^{10}$. These polarization stages 11 have specific functional differences. The pro-inflammatory fibroblast recruits inflammatory cells 12 to the cardiac tissue in response to injury, the proliferative fibroblast undergoes cell division and 13 deposits extracellular matrix in response to TGF- $\beta$, and the mature myofibroblast maintains and 14 strengthens the fibrotic deposits by expressing matrix remodeling proteins ${ }^{11}$. A recent study 15 using single cell RNA sequencing to analyze murine interstitial cells after myocardial infarction 16 revealed fibroblast populations consistent with these polarization states ${ }^{12}$. Despite its 17 importance, we have limited knowledge of the factors that control the passage of myofibroblast 18 through the different stages of differentiation.

19 The Receptor Tyrosine Kinase Like Orphan Receptors 1 and 2 (Ror1 and Ror2) have 20 been evaluated for their roles in development and cell transformation ${ }^{13-15}$. These membrane 21 proteins are most highly expressed in developing tissues ${ }^{16}$, and mice lacking Ror1 display 22 skeletal defects ${ }^{17}$ whereas mice lacking Ror2 have impaired heart and limb development ${ }^{18}$. Ror1 23 and Ror2 expression can be reactivated in various cancers ${ }^{19-24}$, and knockdown or Ror1, Ror2, 24 or both Ror1/2 in various transformed cell lines reduces their proliferation and migration ${ }^{25-28}$. 25 Additionally, Ror1 expression in satellite cells promotes proliferation and skeletal muscle 26 regeneration after injury ${ }^{29}$. These functions of Ror $1 / 2$ may be linked to the ability of this receptor 27 system to control the planar cell polarity signaling pathway. Planar cell polarity is the 28 asymmetrical alignment of cells to coordinate directionality with neighboring cells and 29 extracellular matrix ${ }^{30}$. Proteins in the planar cell polarity pathway, including Ror $1 / 2$ and others 30 (Ptk7, Prickle1, Vangl1, Vangl2, Dvl1, Dvl2, and Dvl3), regulate cell polarity by organizing the 31 actin cytoskeleton and segregating proteins to opposite sides of the cell ${ }^{31}$, 32. In specific cell 32 types, planar cell polarity can regulate proliferation, migration, and cell differentiation ${ }^{33-38}$. Thus it 33 is tempting to speculate that planar cell polarity-mediated actin organization may be critical to 34 myofibroblast function, and that it also functions as an integral step in the actin alignment- 
1 mediated signal transduction that promotes locomotion, contraction, and matrix reorganization

2 during fibroblast differentiation ${ }^{39}$.

3 Although many of the functions attributed to Ror1 and Ror2 are shared by the process of

4 fibroblast activation and differentiation, the roles of Ror1 and Ror2 in myofibroblasts has not

5 been investigated previously. In the course of our studies, we found that Ror1/2 were generally

6 expressed at low levels in the nonchallenged adult mouse tissues. However, the expression of

7 these proteins become markedly in activated fibroblast in response to injurious stimuli. Thus, in

8 this study, we investigated the role of Ror1 and Ror2 in cardiac remodeling through in vivo

9 mouse models of heart failure and in vitro cell culture models of cardiac myofibroblast

10 differentiation.

\section{Methods}

\section{Mouse strains}

All animal experiments were approved by the Animal Care and Use Committees at Boston University and the University of Virginia. Ror1/2//fl $+U b c-C r e^{E R T 2}$ mice were generated by combining Ror1 flox (Jackson Labs \#018353, ${ }^{40}$ ), Ror2 flox (Jackson Labs \#018354, ${ }^{40}$ ), and

17 Ubc-Cre ${ }^{\text {ERT2 }}$ (Jackson Labs \#008085, ${ }^{41}$ ) alleles, which are all in the B6 mouse background.

18 Additionally, Ror2 expression LacZ reporter mice (Ror2-LacZ, ${ }^{42}$ ) were used. Three mice per 19 condition were used for fibroblast isolation experiments and five mice per condition were used for transverse aortic constriction experiments.

Transverse Aortic Constriction (TAC) surgery

23 Cardiac pressure overload by transverse aortic constriction (TAC) was performed as previously described ${ }^{43}$. Briefly, surgery was performed on anesthetized mice where the aortic arch was accessed and constricted between the brachiocephalic artery and left common carotid artery. A 27-gauge spacer was placed parallel to the transverse aorta, and 8-0 vicryl suture (ETHICON Cat \#J401G) was used to ligate the aorta. The spacer was removed, and the surgical wounds were sutured and mouse was allowed to recover. Successful TAC surgery was confirmed by initial expansion of the brachiocephalic artery and subsequent echocardiography

30 measurements (FUJIFILM VisualSonics, Vevo 2100) at 0, 7, 14, and 28 days post-TAC.

31 Fractional shortening was quantified by Cardiac sectioning was performed by cardiac tissue

32 isolation, fixation with 10\% neutral buffered formalin for 24 hours, tissue dehydration, then 33 paraffin-embedding and sectioning. Cardiac tissue sections were either stained for 5-bromo-4-

34 chloro-3-indolyl-b-galactosidase (Xgal; Roche Cat \#XGAL-RO) or immunostained with rabbit 
1 anti-mouse polyclonal Ror2 (provided by Dr. Yasuhiro Minami, Kobe University) with DAB

2 visualization (Vector Laboratories, Cat \#SK-4100), and counterstained with hematoxylin and

3 eosin (Sigma Aldrich, Cat \#HHS128-4L and \#HT110180-2.5L, respectively). Protein lysates

4 from TAC heart samples were isolated from cardiac tissue by $1 \%$ Triton-X supplemented with

5 protease inhibitors and probed for rabbit anti-mouse polyclonal Ror1 (provided by Dr. Michael

6 Greenberg, ${ }^{40}$ ) rabbit anti-mouse monoclonal Ror2 (Cell Signaling Technology Cat \#88639), or

$7 \quad \beta$-actin (Cell Signaling Technology Cat \#4970) by western blot. Cardiac myocytes and cardiac

8 fibroblasts were isolation in a langendorff apparatus as previously described ${ }^{44}$. These primary

9 cells were either used for gene expression analysis after RNA isolation and purification using

10 primers listed in Supplementary Table S1, or analyzed by flow cytometry using the following

11 fluorescently-conjugated antibodies: CD45 (BioLegend Cat \#103126), mEF-SK4 (Miltenyi

12 Biotech Cat \#103-102-352), Ror2 (R\&D Systems Cat \#AF2064).

Primary cardiac cell isolation and fibroblast passaging

Interstitial cells of cardiac tissue were isolated by digestion and cell-type separation, based on previously published methods ${ }^{45}$. Cardiac tissue, either healthy, sham-surgery, or TAC

17 surgery, was isolated from euthanized mice, minced with scissors, and digested in digestion media (HBSS with $0.1 \%$ Trypsin and $100 \mathrm{U} / \mathrm{mL}$ Collagenase Type II) for 80 minutes. CD31+

19 Endothelial Cells and CD45+ Leukocytes were separated and purified by FACS, with BV421

20 Rat anti-Mouse CD31 antibody (BD Biosciences Cat \#562939) and PerCP Rat anti-Mouse

21 CD45 antibody (BD Biosciences Cat \#561047). Fibroblasts were purified by plating on plastic

22 tissue culture dishes for 2 hours in Fibroblast Growth Medium 3 (PromoCell Cat \#c-23130), then

23 media was refed to eliminate cells that had not stuck, leaving the fibroblasts on the tissue

24 culture plate. Genes were assessed by RNA isolation (Qiagen RNeasy Kit Cat\# 74104), reverse

25 transcriptase conversion to DNA (Applied Biosystems cDNA Reverse Transcription Kit Cat 26 \#4368814), and SYBR Green detection (Applied Biosystems Fast SYBR Green Master Mix Cat 27 \#43-856-16) with a quantitative Polymerase Chain Reaction (qPCR) machine (Applied 28 Biosystems QuantStudio 6). Primers for Q-PCR are listed in Supplementary Table S1. 29 Fibroblasts were further passaged and cultured in Fibroblast Growth Medium 3.

\section{Myofibroblast induction}

Isolated cardiac fibroblasts at Passage (P)2 were treated with $10 \mathrm{ng} / \mathrm{mL}$ TGF- $\beta 1$ (R\&D

33 Systems Cat \#240-B) in Fibroblast Growth Medium 3 for four days to assess myofibroblast

34 differentiation. Gene expression was assessed as described above using primers listed in 
1 Supplementary Table S1. Immunofluorescent staining of Acta2 (Cell Signaling Technologies

2 Cat \#36110) and DAPI (ThermoFisher Cat \#62248) was performed by culturing cells in 4-well

3 Chamber slides (ThermoFisher Cat \#154526PK) with 10 ng/mL TGF- $\beta 1$ in Fibroblast Growth

4 Medium 3 for four days, fixation with 4\% PFA for $20 \mathrm{~min}$, permeabilization with PBS-T (PBS +

$50.1 \%$ Tween20), incubation with fluorescent Acta2 antibody, then counterstain with DAPI.

6 Immunostained cells were imaged by confocal microscopy (Leica SP8). Acta2 fiber alignment

7 was quantified by ImageJ (Ver 2.0.0).

\section{Bulk RNA sequencing}

Primary cardiac fibroblasts were isolated as described above from either control mice $\left(\right.$ Ror1/2//fll) or Ror1/2-KO mice (Ror1/2 ${ }^{\mathrm{fl} / f 1}+\mathrm{Ubc}^{\mathrm{fl}}$-CreER ${ }^{\mathrm{T} 2}$ ) after injection with tamoxifen (SigmaAldrich Cat\# T5648) when mice were 6- to 8-weeks old. Each isolation pooled four hearts from mice of the same litter, with the same male:female ratio variation between Control and Ror1/2$\mathrm{KO}$ samples. Mice were bred between a Ror $1 / 2^{\mathrm{fl} / \mathrm{fl}}$ genotype and a Ror1/2f//fl + Ubc-CreER ${ }^{\mathrm{T} 2}$ genotype to generate $\sim 50 \%$ Control mice and $\sim 50 \%$ Ror1/2-KO mice per litter, allowing for littermate paired samples. Specifically, isolations of Control and Ror1/2-KO mice were performed on four different litters with paired samples from the same litters (Ex: Control Sample 1 and Ror1/2KO Sample 1 used hearts from mice of the same litter). Primary cardiac fibroblasts were grown for 9 days in culture, then RNA lysate was isolated and purified. Purified RNA was submitted to the University of Virginia Genome Analysis and Technology Core for whole transcriptome sequencing by first library preparation with NEBNext Ultra II Directional RNA Library Prep Kit for Illumina (NEB Cat \#E7760) and then sequencing by Illumina NextSeq 500 Sequencing System for paired-end $75 \mathrm{bp}$ reads. Programs were used for bioinformatic analysis: raw read data was quality checked with FastQC (Babraham Bioinformatics), aligned with Kallisto ${ }^{46}$, analyzed for gene expression and differential expression with Sleuth ${ }^{47}$, and analyzed for GO term enrichment with $\mathrm{GAGE}^{48}$. Aligned and normalized sequencing results and $\mathrm{GO}$ term enrichment results are provided in Supplementary Data 1-2.

\section{Immunophenotyping of cardiac tissue}

Cardiac tissue was isolated after Sham or TAC surgery. Tissue was digested with collagenase I (450 U/ml), collagenase XI (125 U/ml), DNase I (60 U/ml), and hyaluronidase (60

$32 \mathrm{U} / \mathrm{ml}$ ), and the isolated cells from digested tissue were immunostained with fluorescently33 conjugated antibodies against CD45-Pacific Blue, 30-F11 (BioLegend Cat \#103126), Ly6G-PE, 34 1A8 (BioLegend Cat \#127618), CD11b-APC-Cy7, M1/70 (BioLegend Cat \#101226), F4/80-PE- 
1 Cy7, BM8 (BioLegend Cat \#123114), and Ly6C-FITC, HK1.4 (BioLegend Cat \#128006). Dead

2 cells were excluded by staining with DAPI. Immunostained fluorescent cells were analyzed by

3 Flow Cytometry using BD LSR II Flow Cytometer (BD Bioscience). Additionally, isolated cardiac

4 tissue was lysed and analyzed for inflammatory cytokines II1b, Il6, and Ccl2 by qRT-PCR. Real-

5 time PCR primers are listed in Supplementary Table S1.

\section{Evans Blue staining}

Vascular permeability of the heart after pressure-overload was evaluated by the extent

10 after tail-vein injection of $1 \% \mathrm{w} / \mathrm{v}$ in $0.9 \%$ saline. Dyes were allowed to circulate throughout the 11 body during this period.

Statistical analysis

Unless otherwise indicated, statistical analysis was performed using either a standard two-tail Student's t-test or a two-way ANOVA test followed by a Tukey's multiple comparison corrected post-hoc test by GraphPad Prism (GraphPad Software, Inc., San Diego, CA). All statistical analysis of RNA sequencing datasets was performed through computational analysis packages, which contain statistical corrections for large data sets.

\section{Results}

Transverse aortic constriction induces early Ror1/2 expression in cardiac tissue

Cardiac pressure overload in the mouse model of transverse aortic constriction (TAC)

23 induces fibroblast activation and myocardial remodeling, including initial inflammation (1-3 days

24 post-TAC), extracellular matrix remodeling (3-14 days post-TAC), and eventual heart failure (14-

2528 days post-TAC) ${ }^{49}$. Thus, cardiac tissue was analyzed before and after TAC surgery to

26 investigate the expression patterns of Ror1 and Ror2 during the remodeling time course. The

27 TAC surgery model was initially performed on Ror2-LacZ mice that has the LacZ reporter gene

28 knocked-in to the Ror2 locus ${ }^{42}$. There was no detectable Ror2-mediated LacZ expression in

29 uninjured, or sham-operated mice (Figure 1A and not shown), but $\beta$-galactosidase expression

30 was markedly induced at 7 days post-TAC (Figure 1B). Immunohistochemical analysis revealed

31 that Ror2 protein was concentrated in cells of the interstitial space of the myocardial tissue at 7

32 days post-TAC (Figure 1C). Next, we determined the time course of Ror1 and Ror2 protein

33 induction after TAC surgery by western blot analysis of protein lysates from cardiac tissue. The 
1 expression of both Ror1 and Ror2 protein was increased by three-days post-TAC, peaking at 72 days, and then decreasing at 14- and 28-days post-TAC (Figure 1D).

To determine the cell type(s) that express Ror1 and Ror2, RNA was isolated from endothelial cells, leukocytes, and fibroblasts from sham-operated and TAC-treated hearts 7 days post-surgery, and qPCR was performed to detect the levels of relevant transcripts. Ror1 and Ror2 transcript expression was detected in the activated cardiac fibroblasts at 7 days after TAC, but not in the endothelial or leukocyte cell populations (Figure 1E, Supplemental Figure

8 1). Ror2 protein expression was also detected in fibroblasts after TAC surgery by flow cytometry

9 (Supplemental Figure 2). Overall, the timing, location, and cell-specific gene expression 10 patterns suggest that both Ror1 and Ror2 are induced during the activation and expansion of 11 cardiac fibroblasts that occurs in response to pressure overload-induced myocardial remodeling.

Ror1/2 are induced during early cardiac fibroblast activation

The induction of Ror1/2 during myofibroblast differentiation was also investigated in cultured cells using isolated murine cardiac fibroblasts. Fibroblasts from wild-type murine hearts were attached to cell culture plates, flattened, and expanded over nine days post-isolation

(Supplemental Figure 3). RNA expression of key genes increased at different rates during this activation time course (Figure 2A). As expected, Fsp1 was induced by day 3 and the fibroblast activation genes Slug and Snail increased at day 9. Both Ror1 and Ror2 increased over this time course, but the induction of Ror2 preceded that of Ror1. The planar cell polarity protein transcript Ptk7 increased by day 3 and continued to increase at days 6 and 9, but Prickle and Vangl2 displayed no statistically significant change in expression.

Next, myofibroblast differentiation was stimulated in these cultures by treatment with TGF- $\beta 1$. Myofibroblast differentiation could be detected by cell enlargement and SM $\alpha$-actin filament elongation (Figure 2B-C). However, in contrast to the earlier stage of fibroblast activation, TGF- $\beta 1$ treatment did not lead to a further increase in Ror1 or Ror2 expression. On the other hand, hallmarks of myofibroblast differentiation could be observed following TGF- $\beta 1$ treatment including the increased transcript expression of myofibroblast differentiation proteins Acta2 and Postn, and decreased expression of the cytokines IL-6 and Tnfo (Figure 2D).

30 Together, these data suggest that the induction of Ror1/2 is an early event during fibroblast 31 activation, and that their expression is not altered at the later stages of myofibroblast 32 differentiation. 
We next investigated the role of Ror1/2 in fibroblast activation in the fibroblast cell culture system using primary cardiac fibroblast cells isolated from control or Ror1/2-KO mice. Ror1/2 was eliminated in adult mice through an inducible transgenic knockout strategy by crossing Ror1/2f//fl and Ubc-CreER ${ }^{\mathrm{T} 2}$ mice and treating the progeny with tamoxifen for 2 weeks. These mice displayed no observable phenotype, and they had a normal cardiac phenotype three months after the induction of gene ablation (Supplemental Figure 4). Primary cardiac fibroblasts were isolated from control or Ror1/2-KO mice and grown to confluence. RNA was then isolated, and next-generation RNA sequencing was performed. Many genes associated with a manually curated network of fibrosis and fibroblasts ${ }^{50,51}$ were differentially regulated between control and Ror1/2-KO fibroblasts (Figure 3A). As expected, cells were largely void of Ror1 and Ror2 transcripts, and the planar cell polarity gene Ptk7, Vangl1, Vangl2, Prickle1, Dvl1, Dvl2, Dv/3) were generally reduced in the Ror1/2-KO fibroblasts. Notably, Ror1/2-KO fibroblasts showed an increase in inflammatory cytokine gene expression (I/1a, I/6, Tnfa, Cc/2) and a decrease in transcripts associated with cell proliferation (Pcna, Mki67, Cdk1, Cdk2, Cdk4, Cdk6). Additionally, transcripts associated with the promotion of fibrosis in the ERK1/2 signaling and matrix remodeling pathways were downregulated (Map2k3, Map3k1, Map3k5, Mapk14, Mapk8, Timp1, Timp2), and transcripts associated with the inhibition of fibrosis in the matrix remodeling and natriuretic signaling pathways were upregulated (Mmp2, Mmp9, Mmp14, Nppa, Nppb, Npr1, Npr2, Npr3). Analysis of the top 10 upregulated and downregulated Gene Ontology terms between control and Ror1/2-KO fibroblasts revealed the strong induction of inflammationrelated pathways and an inhibition of proliferation-related and microtubule organization-related pathways (Figure 3B). The specific genes included in these groupings were highly differentially expressed between control and Ror1/2-KO fibroblasts (Figure $3 \mathbf{C}$ ). To the extent that the cell culture system models the early activation of fibroblasts, Ror1/2 dual deficiency led to the upregulation of inflammation pathways and down-regulation of pathways associated with matrix production, proliferation, and microtubule organization. Collectively, these data are consistent with a cellular fibroblast phenotype that appears to be stalled in the pro-inflammatory polarization state, suggesting that Ror $1 / 2$ are required for the progression of fibroblasts from this immature state to the intermediate proliferative state ${ }^{10}$.

Ror1/2 double-knockout fibroblasts are less responsive to TGF- $\beta 1$ induced myofibroblast maturation

Previous findings showed that activated fibroblasts in the early pro-inflammatory state are less responsive to TGF- $\beta$ stimulation than fibroblasts in the intermediate proliferative state ${ }^{10}$. 
1 Thus, to investigate whether the Ror1/2-KO fibroblasts are functionally stalled in an initial pro-

2 inflammatory phenotype, we compared the responsiveness of control and Ror1/2-KO fibroblasts

3 to TGF- $\beta 1$-induced myofibroblast differentiation. In control fibroblasts, TGF- $\beta 1$ treatment led to

4 gene expression changes that are consistent with myofibroblast differentiation (increased Acta2

5 and Postn, decreased IL-6). However, Ror1/2-KO fibroblasts displayed diminished Acta2 and

6 Postn induction and no decrease in IL-6 after TGF- $\beta 1$ treatment when compared to control

7 fibroblasts (Figure 4A, Supplemental Figure 5).

Next, TGF- $\beta 1$-treated control and Ror1/2-KO fibroblasts were visualized after Acta2

10 between control and Ror1/2-KO fibroblasts (Control $=0.073 \pm 0.016 \mathrm{~mm}^{2}$, Ror $1 / 2-\mathrm{KO}=$ $\left.110.071 \pm 0.010 \mathrm{~mm}^{2} ; \mathrm{p}=0.92\right)$, the Acta2 fibers appeared mis-aligned and disorganized in the

12 Ror1/2-KO fibroblasts compared to the Acta2 fiber alignment in the control fibroblasts (Figure

13 4B). Quantification of the directional angle of individual Acta2 fibers within each cell showed that

14 the Acta2 fibers in the Ror1/2-KO fibroblasts were significantly less aligned with each other than

15 the Acta2 fibers in the control fibroblasts (Figure 4C). Taken together, these results show that

16 Ror1/2-KO fibroblasts are less responsive to TGF- $\beta 1$, a feature that is consistent with the notion

17 that these cells are in the less mature, pro-inflammatory state. These results further suggest that

18 the planar cell polarity signaling pathway may be critical for actin alignment during fibroblast

19 maturation.

TAC induces hyper-inflammation, rapid heart failure, and death in Ror1/2 double-knockout mice

To investigate the role of Ror1/2 in cardiac tissue remodeling in vivo, the inducible Ror1/2 double knockout mice (Ror1/2 f/ffl + Ubc-CreER ${ }^{T 2}$ ) were treated with tamoxifen for 2 weeks and subjected to TAC. Ror1/2 double knockout mice displayed a rapid decline in heart function after TAC, as observed by echocardiography measurements at 3 days post-TAC (Figure 5A,B). This rapid development of systolic dysfunction was associated with death of the Ror1/2 double knockout mice between 4- and 6-days post-TAC (Figure 5C). Consistent with the heart failure phenotype, the TAC-treated, Ror1/2 double-knockout mice displayed marked increases in heart and lung weights (Supplemental Figure 6).

Hematoxylin and eosin staining of heart sections revealed a massive inflammatory infiltrate in the Ror1/2 double-knockout mice after TAC (Figure 6A). Inflammatory cell infiltration

32 was further characterized by flow cytometry analysis of cells isolated from digested cardiac 33 tissue at 3 days post-TAC. This analysis revealed a large increase in the number of 34 CD11b+Ly6G+ neutrophils, CD11b+Ly6G-F4/80+ macrophages, and CD11b+Ly6G-Ly6C+ 
1 monocytes in the Ror1/2 double-knockout mice compared to wild-type mice treated by TAC

2 (Figure 6B-C). In Ror1/2 double-knockout mice, TAC also caused a large induction of pro3 inflammatory cytokine gene transcripts including $/ / 1 b$, $/ / 6$, and Ccl2 (Figure 6D). Notably, 4 vascular leakage could also be detected after TAC in the Ror1/2 double-knockout mice as 5 indicated by the permeability of the myocardium to Evans Blue dye (Figure 6E). These data 6 reveal that the hearts of TAC-treated, Ror1/2 double-knockout mice are hyper-inflammatory. 7 This phenotype is consistent with the notion that Ror1/2 is essential for the progression of 8 fibroblast maturation from the initial pro-inflammatory stage during their activation sequence.

\section{Discussion}

Through these experiments we examined the roles of the cell surface receptors Ror1 and Ror2 in cardiac myofibroblast differentiation. We found that Ror1/2 are upregulated in

13 fibroblasts early after activation, both in vivo by pressure-overload cardiac injury induced by

14 TAC surgery and in cardiac fibroblast cell culture. Multiple lines of data indicate that dual Ror1/2 15 deficiency impairs myofibroblast differentiation. Specifically, cultured Ror1/2-KO fibroblasts 16 exhibited an immature, pro-inflammatory state and they were impaired in their response to TGF-

$17 \beta 1$ stimulation. Additionally, while mice lacking Ror1/2 did not exhibit a baseline phenotype, they 18 were unable to acutely adapt to pressure overload cardiac injury. In response to TAC, these 19 mice underwent profound decompensated remodeling by 3 days and they typically died within 20 6-days of surgery. Collectively, these results suggest that the early induction of Ror1/2 in 21 fibroblasts is essential for the appropriate myofibroblast differentiation and required for the 22 myocardium to adapt to the initial stages of pressure overload injury.

The phenotype of the Ror1/2 double-knockout mice highlighted a critical role for Ror $1 / 2$ 24 in controlling the inflammatory phenotype of fibroblasts during the early stages of cardiac 25 remodeling. The rapid upregulation of cytokines in response to TAC injury leads to the 26 infiltration of neutrophils and monocyte-derived macrophages ${ }^{43}$, 52 . Several recent studies have 27 highlighted the role of fibroblasts in promoting inflammation during the initial phases of the 28 cardiac remodeling response to myocardial infarction ${ }^{10,53}$ and pressure overload ${ }^{54,55}$. Our 29 results expand on these studies by showing that fibroblasts lacking Ror1/2 appear to be 30 phenotypically similar to fibroblasts in the transient, pro-inflammatory state that occurs early in 31 the fibroblast differentiation continuum following experimental myocardial infarction ${ }^{10}$. 32 Transcriptomic analyses of cultured cardiac fibroblasts revealed that Ror1/2-deficiency was 33 associated with a decrease in pathways that promote fibrosis (proliferation genes, ERK1/2 34 signaling genes, tissue inhibitors of matrix metalloproteinases, and Smad2/3) and an increase in 
1 pathways that inhibit fibrosis (inflammatory cytokines, matrix metalloproteinases, and natriuretic

2 signaling genes). These differences in gene expression suggest that the Ror1/2-KO fibroblasts

3 are in an immature state that is pro-inflammatory, leukocyte-recruiting and less responsive to

4 fibrotic stimuli. We confirmed this by showing that Ror1/2-KO fibroblasts were less responsive to

5 TGF- $\beta 1$ compared to control fibroblasts, displaying reduced induction of Acta2 and Postn gene

6 expression and diminished repression of $/ 16$ gene expression. Thus, we propose that Ror1/2-

7 deficiency causes activated fibroblasts to stall in an early pro-inflammatory state of

8 differentiation such that they are unable to efficiently transition to the intermediate proliferative

9 state and mature homeostatic state. Also consistent with this hypothesis, we found that Ror $1 / 2$

10 double knockout mice exhibit a hyper-inflammatory phenotype associated with elevated

11 cytokine transcript expression, exuberant inflammatory cell infiltration and vascular leakage

12 within 3 days of TAC surgery. These results highlight the critical role of early Ror1/2 induction in

13 the control of the early inflammatory response in the injured myocardium, and suggest that

14 hyper-inflammatory activated fibroblasts can have a detrimental role in myocardial remodeling.

15 In myofibroblasts, appropriate SM $\alpha$-actin stress fiber organization is required for the

16 transduction of signaling responses to external stimuli ${ }^{39}$, and the misalignment of SM $\alpha$-actin

17 stress fibers is associated with dysregulated myofibroblast differentiation ${ }^{56,57}$. Consistent with

18 the notion that Ror1/2 induction is essential for myofibroblast differentiation, we find that Ror1/2-

19 deficiency leads to SM $\alpha$-actin filament misalignment in TGF- $\beta 1$-treated fibroblasts. Ror1/2

20 signaling can control stress fiber alignment, myofibroblast differentiation and other cellular

21 phenotypes through the regulation of upstream and downstream planar cell polarity

22 components ${ }^{13,43,58-63}$. This system involves the participation of inner plasma membrane proteins

23 associated with Ror1/2 that control cell polarity and asymmetric cell division through the

24 regulation of actin filament organization by the action of the small GTPases RhoA and Rac ${ }^{31,32}$.

25 Our work is consistent with other studies that have implicated planar cell polarity proteins in

26 myofibroblast differentiation, including the reported induction of Frizzled2 in myofibroblasts after

27 experimental myocardial infarction ${ }^{64}$ and hypoxia-mediated suppression of myofibroblast

28 differentiation through RhoA inhibition ${ }^{65}$. Furthermore, ablation of Smad3, a key signaling

29 protein downstream of TGF- $\beta$ cardiac fibroblasts ${ }^{66}$, will lead to the suppression of RhoA and a

30 disruption of actin alignment ${ }^{57}$. Together, these results suggest a potential role of planar cell

31 polarity signaling in mediating stress fiber organization and TGF- $\beta$ response in activated cardiac

32 fibroblasts.

33 We acknowledge that Ror1/2 double-deficient mice were constructed using a global 34 knockout strategy that employed ubiquitin-CreER ${ }^{\top 2}$. As discussed, these mice lack a baseline 
1 phenotype, yet undergo rapid decompensated heart failure and death in response to pressure

2 overload. Although we cannot rule out the contribution of other cell types lacking Ror1/2 to this

3 phenotype, we note that Ror1/2 expression appears specific to activated cardiac fibroblasts

4 under these conditions. Our experimental evidence in support of this include that expression of

5 Ror1/2 was greatly increased after TAC-induced cardiac injury in the interstitial cells of the

6 myocardium, and the TAC-induced upregulation of Ror1/2 gene expression was specific to

7 fibroblasts with no Ror1/2 induction in endothelial cells or leukocytes. Consistent with these

8 findings, a number of other studies have reported Ror1 and/or Ror2 expression in activated

9 fibroblasts or fibroblast-like cells ${ }^{12,67-70}$, and a recent proteomic analysis of the human heart

10 reported that ROR1 expression was 200 -fold higher in than cardiac fibroblasts than other

11 cardiac cell types ${ }^{71}$. In addition, studies with isolated fibroblasts further corroborate the in vivo

12 observations. These in vitro studies documented the robust expression of Ror $1 / 2$ and

13 associated planar cell polarity protein transcripts (Ptk7, Vangl1 and 2, Prickle1 and Dvl1, 2 and

143 ) in activated cardiac fibroblasts, and showed that the ablation of Ror $1 / 2$ leads to a

15 proinflammatory phenotype that is consistent with the cardiac phenotype of the Ror1/2-deficient

16 mouse following TAC surgery.

17 Conclusion. Cardiac fibroblasts are sentinel cells in the heart that respond to early injury

18 by adopting a proinflammatory and leukocyte-recruiting phenotype, followed by their transition to

19 a reparative/proliferative phase that is pro-angiogenic and pro-fibrotic, and followed by a

20 homeostatic phase. Our study reveals the critical role that the cell surface receptors Ror $1 / 2$ play

21 in allowing myofibroblasts to appropriately transition through these phases. While the deficiency

22 of these proteins has no detectable baseline phenotype, Ror1/2-deficient fibroblasts activated

23 by pressure overload appears stalled in the early phase of the fibroblast differentiation

24 continuum - a stage of differentiation that is highly pro-inflammatory. Further analysis of the

25 injury-induced, hyper-inflammatory phenotype of the Ror1/2 double knockout mice may provide

26 a greater window of understanding of how excessive inflammation contributes to pathological

27 cardiac remodeling. Elevated inflammation is predictive of worse outcomes in patients with heart

28 failure ${ }^{72,73}$, and recent clinical trials of anti-inflammatory therapies targeting IL-1 $\beta$ and IL-1R1

29 have shown promising results in the treatment of this condition in some patient groups ${ }^{74-76}$. Our

30 results suggest that impairments in planar cell polarity-mediated regulation of myofibroblast

31 differentiation could have a causative role in the development of excessive inflammation that is

32 associated with heart failure. Therefore, a better understanding of the molecular mechanisms

33 that regulate the progression of myofibroblast differentiation could provide opportunities for the

34 development of therapies that more effectively reduce cardiac inflammation. 
2 Acknowledgements

We would like to thank the University of Virginia Genome Analysis and Technology Core

4 for advice and technical support on bulk RNA sequencing, and the University of Virginia Health

5 Sciences Library and Research Computing Center for assistance with computational analysis.

\section{Sources of Funding}

8 This study was supported by grants to N.W.C. (NIH T32 HL007224, NIH T32 9 HL007284), S.S. (NIH R01 HL152174), Y.W. (China Scholarship Council), H.O. (Japan Heart 10 Foundation), A.N. (NIH T32 HL007284), J.S. (NIH R01 HL137755), K.K.H. (R01 HL146056, 11 U2EB017103), K.W. (NIH R01 HL138014,139819 and HL141256) and N.G and K.W. (NIH R01 12 HL142650).

13

\section{Disclosures}

15 The authors have no conflicts of interest to disclose.

\section{Supplemental Materials}

18 Supplemental Figures 1-6

19 Supplemental Table 1 


\section{References}

1. Fan D, Takawale A, Lee J, Kassiri Z. Cardiac fibroblasts, fibrosis and extracellular matrix remodeling in heart disease. Fibrogenesis Tissue Repair. 2012;5:15

2. van den Borne SW, Diez J, Blankesteijn WM, Verjans J, Hofstra L, Narula J. Myocardial remodeling after infarction: The role of myofibroblasts. Nat Rev Cardiol. 2010;7:30-37

3. Tallquist MD, Molkentin JD. Redefining the identity of cardiac fibroblasts. Nat Rev Cardiol. 2017; 14:484-491

4. Kanisicak O, Khalil H, Ivey MJ, Karch J, Maliken BD, Correll RN, Brody MJ, SC JL, Aronow BJ, Tallquist MD, Molkentin JD. Genetic lineage tracing defines myofibroblast origin and function in the injured heart. Nat Commun. 2016;7:12260

5. Oka T, Xu J, Kaiser RA, Melendez J, Hambleton M, Sargent MA, Lorts A, Brunskill EW, Dorn GW, Conway SJ, Aronow BJ, Robbins J, Molkentin JD. Genetic manipulation of periostin expression reveals a role in cardiac hypertrophy and ventricular remodeling. Circ Res. 2007;101:313-321

6. Maruyama S, Nakamura K, Papanicolaou KN, Sano S, Shimizu I, Asaumi Y, van den Hoff MJ, Ouchi N, Recchia FA, Walsh K. Follistatin-like 1 promotes cardiac fibroblast activation and protects the heart from rupture. EMBO Mol Med. 2016;8:949-966

7. Richardson WJ, Clarke SA, Quinn TA, Holmes JW. Physiological implications of myocardial scar structure. Compr Physiol. 2015;5:1877-1909

8. Weber KT, Brilla CG, Janicki JS. Myocardial fibrosis: Functional significance and regulatory factors. Cardiovasc Res. 1993;27:341-348

9. Frangogiannis NG. The extracellular matrix in ischemic and nonischemic heart failure. Circ Res. 2019;125:117-146

10. Mouton AJ, Ma Y, Rivera Gonzalez OJ, Daseke MJ, 2nd, Flynn ER, Freeman TC, Garrett MR, DeLeon-Pennell KY, Lindsey ML. Fibroblast polarization over the myocardial infarction time continuum shifts roles from inflammation to angiogenesis. Basic Res Cardiol. 2019;114:6

11. Daseke MJ, Tenkorang MAA, Chalise U, Konfrst SR, Lindsey ML. Cardiac fibroblast activation during myocardial infarction wound healing: Fibroblast polarization after mi. Matrix Biol. 2020

12. Farbehi N, Patrick R, Dorison A, Xaymardan M, Janbandhu V, Wystub-Lis K, Ho JWK, Nordon RE, Harvey RP. Single-cell expression profiling reveals dynamic flux of cardiac stromal, vascular and immune cells in health and injury. eLife. 2019;8 
13. Liu Y, Rubin B, Bodine PV, Billiard J. Wnt5a induces homodimerization and activation of ror2 receptor tyrosine kinase. J Cell Biochem. 2008;105:497-502

14. Katoh M. Wnt/pcp signaling pathway and human cancer (review). Oncol Rep. 2005;14:1583-1588

15. Komiya Y, Habas R. Wnt signal transduction pathways. Organogenesis. 2008;4:68-75

16. Matsuda T, Nomi M, Ikeya M, Kani S, Oishi I, Terashima T, Takada S, Minami Y. Expression of the receptor tyrosine kinase genes, ror1 and ror2, during mouse development. Mech Dev. 2001;105:153-156

17. Lyashenko N, Weissenbock M, Sharir A, Erben RG, Minami Y, Hartmann C. Mice lacking the orphan receptor ror1 have distinct skeletal abnormalities and are growth retarded. Dev Dyn. 2010;239:2266-2277

18. Takeuchi S, Takeda K, Oishi I, Nomi M, Ikeya M, Itoh K, Tamura S, Ueda T, Hatta T, Otani H, Terashima T, Takada S, Yamamura H, Akira S, Minami Y. Mouse ror2 receptor tyrosine kinase is required for the heart development and limb formation. Genes Cells. 2000;5:71-78

19. Kobayashi M, Shibuya Y, Takeuchi J, Murata M, Suzuki H, Yokoo S, Umeda M, Minami Y, Komori T. Ror2 expression in squamous cell carcinoma and epithelial dysplasia of the oral cavity. Oral Surg Oral Med Oral Pathol Oral Radiol Endod. 2009;107:398-406

20. Daneshmanesh AH, Porwit A, Hojjat-Farsangi M, Jeddi-Tehrani M, Tamm KP, Grandér D, Lehmann S, Norin S, Shokri F, Rabbani H, Mellstedt H, Österborg A. Orphan receptor tyrosine kinases ror1 and ror2 in hematological malignancies. Leuk Lymphoma. 2013;54:843-850

21. Henry CE, Emmanuel C, Lambie N, Loo C, Kan B, Kennedy CJ, de Fazio A, Hacker NF, Ford CE. Distinct patterns of stromal and tumor expression of ror1 and ror2 in histological subtypes of epithelial ovarian cancer. Trans/ Oncol. 2017;10:346-356

22. Bayerlová M, Menck K, Klemm F, Wolff A, Pukrop T, Binder C, Beißbarth T, Bleckmann A. Ror2 signaling and its relevance in breast cancer progression. Front Oncol. 2017;7:135

23. Henry CE, Llamosas E, Daniels B, Coopes A, Tang K, Ford CE. Ror1 and ror2 play distinct and opposing roles in endometrial cancer. Gynecol Oncol. 2018;148:576-584

24. Liu D, Gunther K, Enriquez LA, Daniels B, O'Mara TA, Tang K, Spurdle AB, Ford CE. Ror1 is upregulated in endometrial cancer and represents a novel therapeutic target. Sci Rep. 2020;10:13906 
25. Henry C, Hacker N, Ford C. Silencing ror1 and ror2 inhibits invasion and adhesion in an organotypic model of ovarian cancer metastasis. Oncotarget. 2017:112727-112738.

26. Saji T, Nishita M, Ogawa H, Doi T, Sakai Y, Maniwa Y, Minami Y. Critical role of the rorfamily of receptor tyrosine kinases in invasion and proliferation of malignant pleural mesothelioma cells. Genes Cells. 2018;23:606-613

27. Yu J, Chen L, Cui B, Widhopf GF, 2nd, Shen Z, Wu R, Zhang L, Zhang S, Briggs SP, Kipps TJ. Wnt5a induces ror1/ror2 heterooligomerization to enhance leukemia chemotaxis and proliferation. J Clin Invest. 2016;126:585-598

28. Zhang S, Chen L, Cui B, Chuang HY, Yu J, Wang-Rodriguez J, Tang L, Chen G, Basak GW, Kipps TJ. Ror1 is expressed in human breast cancer and associated with enhanced tumor-cell growth. PLoS One. 2012;7:e31127

29. Kamizaki K, Doi R, Hayashi M, Saji T, Kanagawa M, Toda T, Fukada SI, Ho HH, Greenberg ME, Endo M, Minami Y. The ror1 receptor tyrosine kinase plays a critical role in regulating satellite cell proliferation during regeneration of injured muscle. $J$ Biol Chem. 2017;292:15939-15951

30. Butler MT, Wallingford JB. Planar cell polarity in development and disease. Nat Rev Mol Cell Biol. 2017;18:375-388

31. Seifert JR, Mlodzik M. Frizzled/pcp signalling: A conserved mechanism regulating cell polarity and directed motility. Nat Rev Genet. 2007;8:126-138

32. Gao B, Song H, Bishop K, Elliot G, Garrett L, English MA, Andre P, Robinson J, Sood R, Minami Y, Economides AN, Yang Y. Wnt signaling gradients establish planar cell polarity by inducing vangl2 phosphorylation through ror2. Dev Cell. 2011;20:163-176

33. Bradley EW, Drissi $\mathrm{MH}$. Wnt5b regulates mesenchymal cell aggregation and chondrocyte differentiation through the planar cell polarity pathway. J Cell Physiol. 2011;226:1683-1693

34. Brzoska HL, d'Esposito AM, Kolatsi-Joannou M, Patel V, Igarashi P, Lei Y, Finnell RH, Lythgoe MF, Woolf AS, Papakrivopoulou E, Long DA. Planar cell polarity genes celsr1 and vangl 2 are necessary for kidney growth, differentiation, and rostrocaudal patterning. Kidney Int. 2016;90:1274-1284

35. Cortijo C, Gouzi M, Tissir F, Grapin-Botton A. Planar cell polarity controls pancreatic beta cell differentiation and glucose homeostasis. Cell Rep. 2012;2:1593-1606

36. Vladar EK, Nayak JV, Milla CE, Axelrod JD. Airway epithelial homeostasis and planar cell polarity signaling depend on multiciliated cell differentiation. JCI Insight. 2016;1 
37. Wada $\mathrm{H}$, Okamoto $\mathrm{H}$. Roles of planar cell polarity pathway genes for neural migration and differentiation. Dev Growth Differ. 2009;51:233-240

38. Yang X, Qian X, Ma R, Wang X, Yang J, Luo W, Chen P, Chi F, Ren D. Establishment of planar cell polarity is coupled to regional cell cycle exit and cell differentiation in the mouse utricle. Sci Rep. 2017;7:43021

39. Sandbo N, Dulin N. Actin cytoskeleton in myofibroblast differentiation: Ultrastructure defining form and driving function. Trans/ Res. 2011;158:181-196

40. Ho HY, Susman MW, Bikoff JB, Ryu YK, Jonas AM, Hu L, Kuruvilla R, Greenberg ME. Wnt5a-ror-dishevelled signaling constitutes a core developmental pathway that controls tissue morphogenesis. Proc Natl Acad Sci U S A. 2012;109:4044-4051

41. Ruzankina Y, Pinzon-Guzman C, Asare A, Ong T, Pontano L, Cotsarelis G, Zediak VP, Velez M, Bhandoola A, Brown EJ. Deletion of the developmentally essential gene atr in adult mice leads to age-related phenotypes and stem cell loss. Cell Stem Cell. 2007;1:113-126

42. DeChiara TM, Kimble RB, Poueymirou WT, Rojas J, Masiakowski P, Valenzuela DM, Yancopoulos GD. Ror2, encoding a receptor-like tyrosine kinase, is required for cartilage and growth plate development. Nat Genet. 2000;24:271-274

43. Wang Y, Sano S, Oshima K, Sano M, Watanabe Y, Katanasaka Y, Yura Y, Jung C, Anzai A, Swirski FK, Gokce N, Walsh K. Wnt5a-mediated neutrophil recruitment has an obligatory role in pressure overload-induced cardiac dysfunction. Circulation. 2019;140:487-499

44. Papanicolaou KN, Streicher JM, Ishikawa TO, Herschman H, Wang Y, Walsh K. Preserved heart function and maintained response to cardiac stresses in a genetic model of cardiomyocyte-targeted deficiency of cyclooxygenase-2. J Mol Cell Cardiol. 2010;49:196-209

45. Zafiriou MP, Noack C, Unsöld B, Didie M, Pavlova E, Fischer HJ, Reichardt HM, Bergmann MW, El-Armouche A, Zimmermann WH, Zelarayan LC. Erythropoietin responsive cardiomyogenic cells contribute to heart repair post myocardial infarction. Stem Cells. 2014;32:2480-2491

46. Bray NL, Pimentel H, Melsted P, Pachter L. Near-optimal probabilistic rna-seq quantification. Nat Biotechnol. 2016;34:525-527

47. Pimentel H, Bray NL, Puente S, Melsted P, Pachter L. Differential analysis of rna-seq incorporating quantification uncertainty. Nat Methods. 2017;14:687-690 
48. Luo W, Friedman MS, Shedden K, Hankenson KD, Woolf PJ. Gage: Generally applicable gene set enrichment for pathway analysis. BMC Bioinformatics. 2009;10:161

49. deAlmeida AC, van Oort RJ, Wehrens $\mathrm{XH}$. Transverse aortic constriction in mice. $J$ vis exp. 2010.

50. Zeigler AC, Richardson WJ, Holmes JW, Saucerman JJ. A computational model of cardiac fibroblast signaling predicts context-dependent drivers of myofibroblast differentiation. J Mol Cell Cardiol. 2016;94:72-81

51. Zeigler AC, Nelson AR, Chandrabhatla AS, Brazhkina O, Holmes JW, Saucerman JJ. Computational model predicts paracrine and intracellular drivers of fibroblast phenotype after myocardial infarction. Matrix Biol. 2020

52. Patel B, Bansal SS, Ismahil MA, Hamid T, Rokosh G, Mack M, Prabhu SD. Ccr2 + monocyte-derived infiltrating macrophages are required for adverse cardiac remodeling during pressure overload. JACC Basic Trans/ Sci. 2018;3:230-244

53. Farbehi N, Patrick R, Dorison A, Xaymardan M, Janbandhu V, Wystub-Lis K, Ho JW, Nordon RE, Harvey RP. Single-cell expression profiling reveals dynamic flux of cardiac stromal, vascular and immune cells in health and injury. Elife. 2019;8

54. Unudurthi SD, Nassal DM, Patel NJ, Thomas E, Yu J, Pierson CG, Bansal SS, Mohler PJ, Hund TJ. Fibroblast growth factor-inducible 14 mediates macrophage infiltration in heart to promote pressure overload-induced cardiac dysfunction. Life Sci. 2020;247:117440

55. Suzuki K, Satoh K, Ikeda S, Sunamura S, Otsuki T, Satoh T, Kikuchi N, Omura J, Kurosawa R, Nogi M, Numano K, Sugimura K, Aoki T, Tatebe S, Miyata S, Mukherjee R, Spinale FG, Kadomatsu K, Shimokawa H. Basigin promotes cardiac fibrosis and failure in response to chronic pressure overload in mice. Arterioscler Thromb Vasc Biol. 2016;36:636-646

56. Wang YS, Li SH, Guo J, Mihic A, Wu J, Sun L, Davis K, Weisel RD, Li RK. Role of mir145 in cardiac myofibroblast differentiation. J Mol Cell Cardiol. 2014;66:94-105

57. Huang S, Chen B, Su Y, Alex L, Humeres C, Shinde AV, Conway SJ, Frangogiannis NG. Distinct roles of myofibroblast-specific smad2 and smad3 signaling in repair and remodeling of the infarcted heart. $J$ Mol Cell Cardiol. 2019;132:84-97

58. Xiao $Q$, Chen Z, Jin X, Mao R. The many postures of noncanonical wnt signaling in development and diseases. Biomed Pharmacother. 2017;93:359-369 
59. Abdolmaleki F, Ahmadpour-Yazdi H, Hayat SMG, Gheibi N, Johnston TP, Sahebkar A. Wnt network: A brief review of pathways and multifunctional components. Crit Rev Eukaryot Gene Expr. 2020;30:1-18

60. Nakamura K, Sano S, Fuster JJ, Kikuchi R, Shimizu I, Ohshima K, Katanasaka Y, Ouchi N, Walsh K. Secreted frizzled-related protein 5 diminishes cardiac inflammation and protects the heart from ischemia/reperfusion injury. Journal of Biological Chemistry. 2016;291:2566-2575

61. Kikuchi R, Nakamura K, MacLauchlan S, Ngo DT, Shimizu I, Fuster JJ, Katanasaka Y, Yoshida S, Qiu Y, Yamaguchi TP, Matsushita T, Murohara T, Gokce N, Bates DO, Hamburg NM, Walsh K. An antiangiogenic isoform of vegf-a contributes to impaired vascularization in peripheral artery disease. Nat Med. 2014;20:1464-1471

62. Fuster JJ, Zuriaga MA, Ngo DT, Farb MG, Aprahamian T, Yamaguchi TP, Gokce N, Walsh K. Noncanonical wnt signaling promotes obesity-induced adipose tissue inflammation and metabolic dysfunction independent of adipose tissue expansion. Diabetes. 2015;64:1235-1248

63. Hagenmueller M, Riffel JH, Bernhold E, Fan J, Katus HA, Hardt SE. Dapper-1 is essential for wnt5a induced cardiomyocyte hypertrophy by regulating the wnt/pcp pathway. FEBS Lett. 2014;588:2230-2237

64. Blankesteijn WM, Essers-Janssen YP, Verluyten MJ, Daemen MJ, Smits JF. A homologue of drosophila tissue polarity gene frizzled is expressed in migrating myofibroblasts in the infarcted rat heart. Nat Med. 1997;3:541-544

65. Leinhos L, Peters J, Krull S, Helbig L, Vogler M, Levay M, van Belle GJ, Ridley AJ, Lutz $S$, Katschinski DM, Zieseniss A. Hypoxia suppresses myofibroblast differentiation by changing rhoa activity. J Cell Sci. 2019;132

66. Khalil H, Kanisicak O, Prasad V, Correll RN, Fu X, Schips T, Vagnozzi RJ, Liu R, Huynh T, Lee SJ, Karch J, Molkentin JD. Fibroblast-specific tgf-beta-smad2/3 signaling underlies cardiac fibrosis. J Clin Invest. 2017;127:3770-3783

67. Li X, Yamagata K, Nishita M, Endo M, Arfian N, Rikitake Y, Emoto N, Hirata K, Tanaka Y, Minami Y. Activation of wnt5a-ror2 signaling associated with epithelial-tomesenchymal transition of tubular epithelial cells during renal fibrosis. Genes Cells. 2013;18:608-619

68. Takahashi D, Suzuki H, Kakei Y, Yamakoshi K, Minami Y, Komori T, Nishita M. Expression of ror2 associated with fibrosis of the submandibular gland. Cell Struct Funct. 2017;42:159-167 
69. Li C, Smith SM, Peinado N, Gao F, Li W, Lee MK, Zhou B, Bellusci S, Pryhuber GS, Ho $\mathrm{HH}$, Borok Z, Minoo P. Wnt5a-ror signaling is essential for alveologenesis. Cells. 2020;9

70. Wilson DH, Jarman EJ, Mellin RP, Wilson ML, Waddell SH, Tsokkou P, Younger NT, Raven A, Bhalla SR, Noll ATR, Olde Damink SW, Schaap FG, Chen P, Bates DO, Banales JM, Dean CH, Henderson DJ, Sansom OJ, Kendall TJ, Boulter L. Noncanonical wnt signalling regulates scarring in biliary disease via the planar cell polarity receptors. Nat Commun. 2020;11:445

71. Doll S, Dreßen M, Geyer PE, Itzhak DN, Braun C, Doppler SA, Meier F, Deutsch MA, Lahm $H$, Lange $R$, Krane M, Mann M. Region and cell-type resolved quantitative proteomic map of the human heart. Nat Commun. 2017;8:1469

72. Kardys I, Knetsch AM, Bleumink GS, Deckers JW, Hofman A, Stricker BH, Witteman JC. C-reactive protein and risk of heart failure. The rotterdam study. Am Heart J. 2006;152:514-520

73. Kalogeropoulos A, Georgiopoulou V, Psaty BM, Rodondi N, Smith AL, Harrison DG, Liu Y, Hoffmann U, Bauer DC, Newman AB, Kritchevsky SB, Harris TB, Butler J, Investigators HAS. Inflammatory markers and incident heart failure risk in older adults: The health abc (health, aging, and body composition) study. J Am Coll Cardiol. 2010;55:2129-2137

74. Everett BM, Cornel JH, Lainscak M, Anker SD, Abbate A, Thuren T, Libby P, Glynn RJ, Ridker PM. Anti-inflammatory therapy with canakinumab for the prevention of hospitalization for heart failure. Circulation. 2019;139:1289-1299

75. Abbate A, Toldo S, Marchetti C, Kron J, Van Tassell BW, Dinarello CA. Interleukin-1 and the inflammasome as therapeutic targets in cardiovascular disease. Circ Res. 2020;126:1260-1280

76. Van Tassell BW, Canada J, Carbone S, Trankle C, Buckley L, Oddi Erdle C, Abouzaki NA, Dixon D, Kadariya D, Christopher S, Schatz A, Regan J, Viscusi M, Del Buono M, Melchior R, Mankad P, Lu J, Sculthorpe R, Biondi-Zoccai G, Lesnefsky E, Arena R, Abbate A. Interleukin-1 blockade in recently decompensated systolic heart failure: Results from redhart (recently decompensated heart failure anakinra response trial). Circ Heart Fail. 2017;10 


\section{Figures}

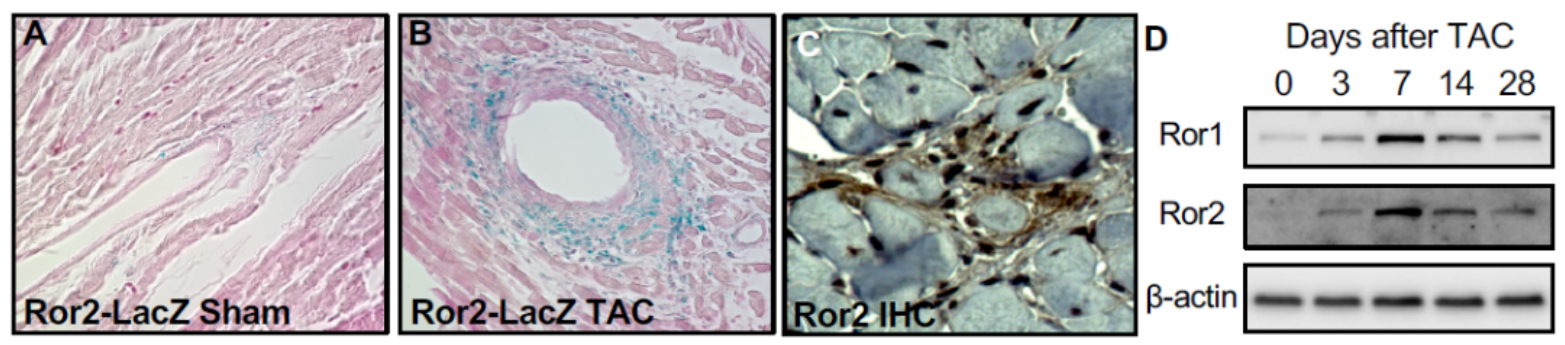

E

$\square$ Endothelial Cells $\square$ Leukocytes $\square$ Fibroblasts
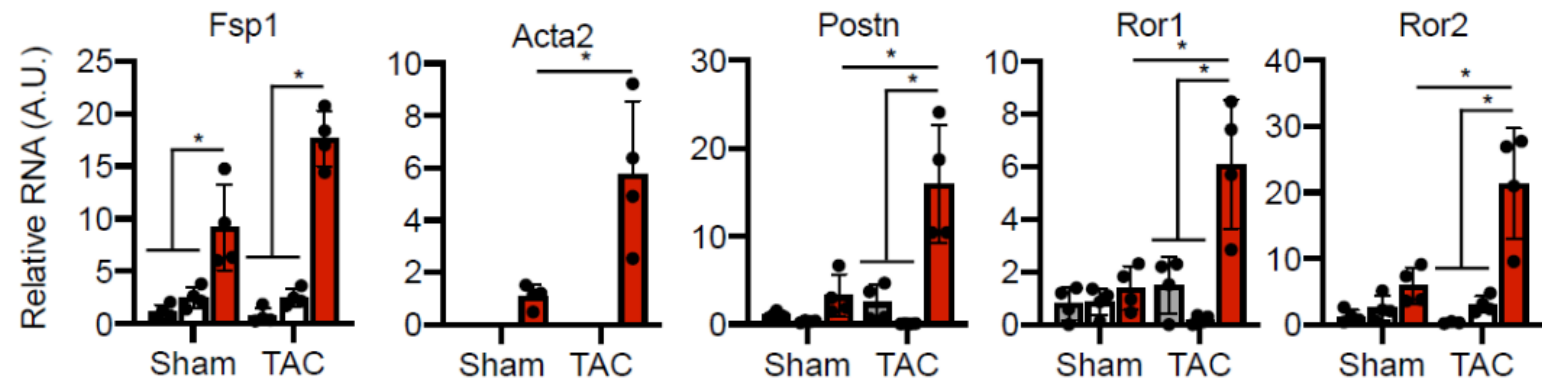

Figure 1. Ror1 and Ror2 expression after Transverse Aortic Constriction in mice. Cells expressing Ror2 in cardiac tissue was visualized in Ror2-LacZ mice 28 days after A) sham surgery or B) TAC surgery. C) Protein localization was visualized in cardiac tissue 7 days after TAC by IHC for Ror2. D) Ror1 and Ror2 protein expression was measured by western blot at various days after TAC surgery ( $\beta$-actin as a loading control). E) Endothelial cells, leukocytes, and fibroblasts were isolated 7 days after Sham or TAC surgery, and RNA expression of relevant genes was quantified. 
A $\square$ Day $0 \square$ Day $3 \square$ Day $6 \square$ Day 9
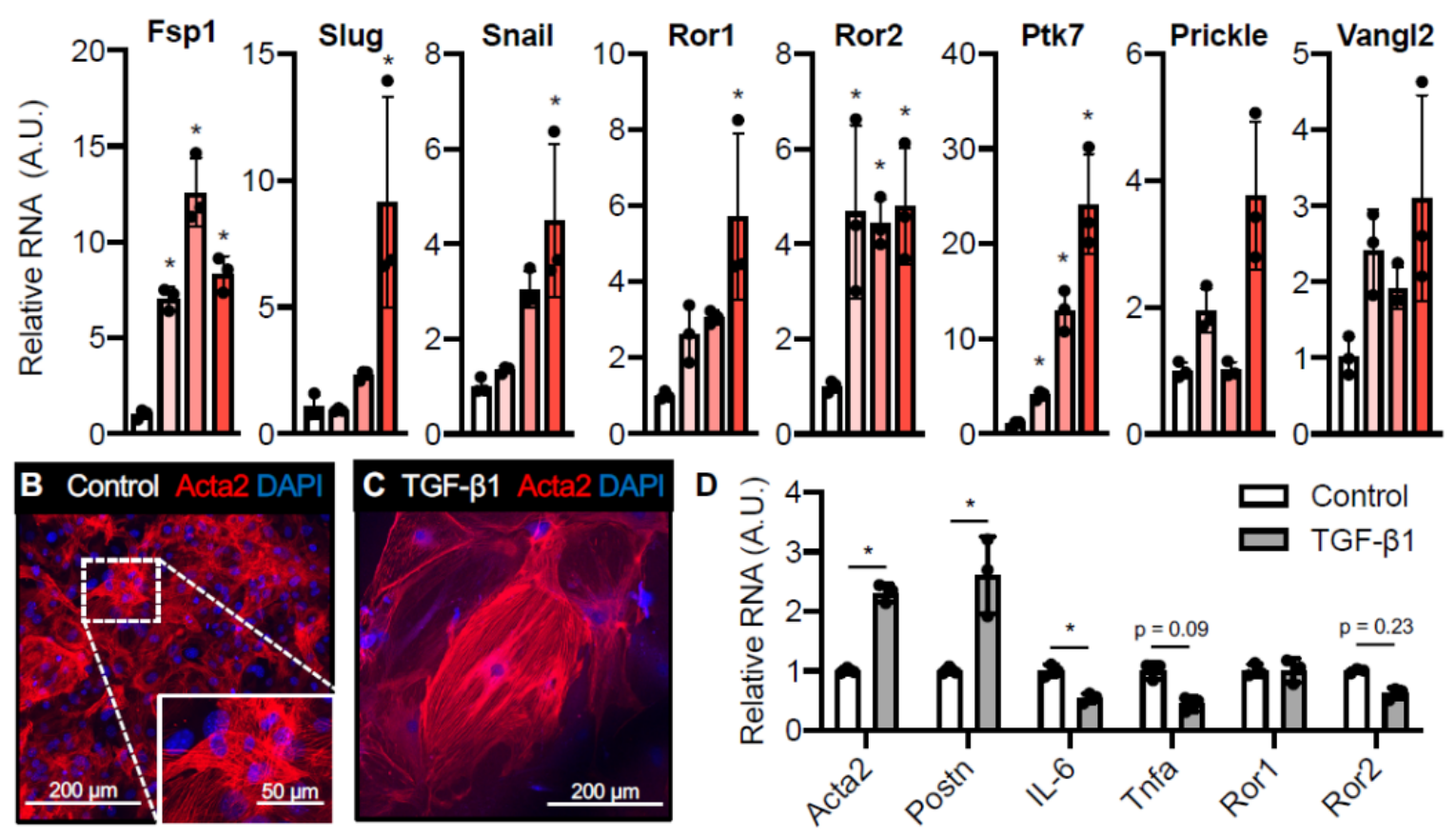

Figure 2. Induction of Ror1 and Ror2 during early fibroblast activation and induction of myofibroblast differentiation of murine cardiac fibroblasts. Murine cardiac fibroblasts were isolated from healthy cardiac tissue of C57BI6 mice. A) RNA expression of genes associated with fibroblast identity, fibroblast activation, Ror1/2 receptors, and planar cell polarity signaling was quantified over time. Cardiac myofibroblasts at passage 2 were stained for SMal-actin fibers after B) control and C) TGF- $\beta 1$ treatment. D) RNA expression of genes associated with myofibroblast differentiation, inflammation, and Ror1/2 receptors was quantified in control and TGF- $\beta 1$ treated fibroblasts. 
A

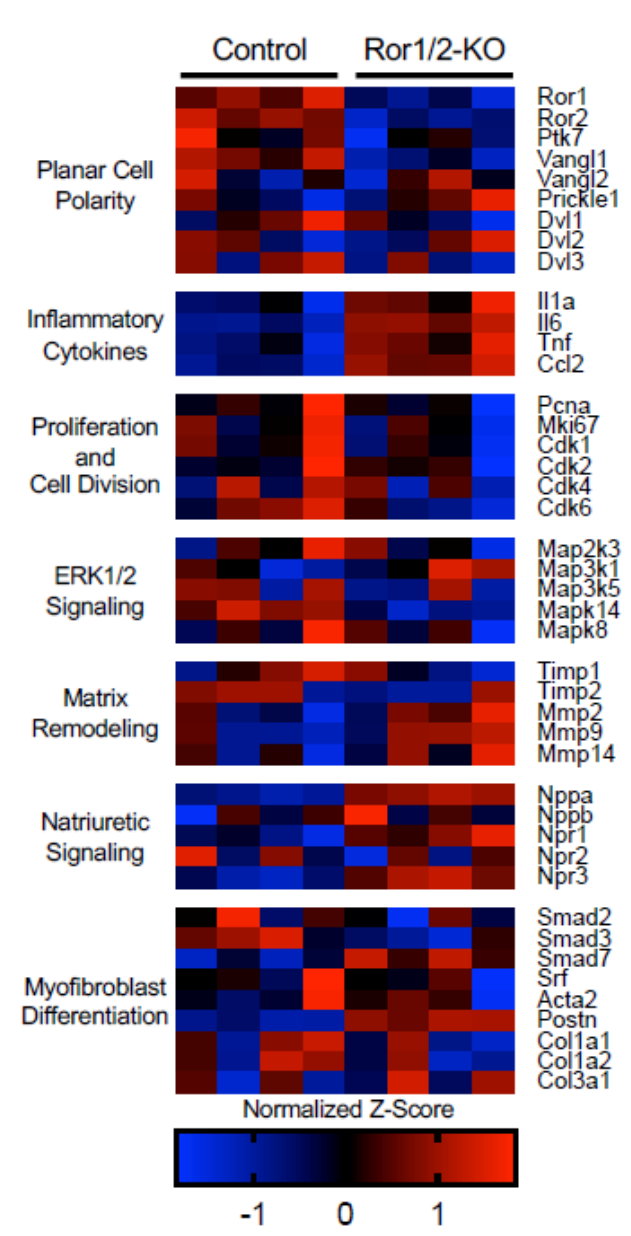

B GO-Term Analysis of Control vs Ror1/2-KO

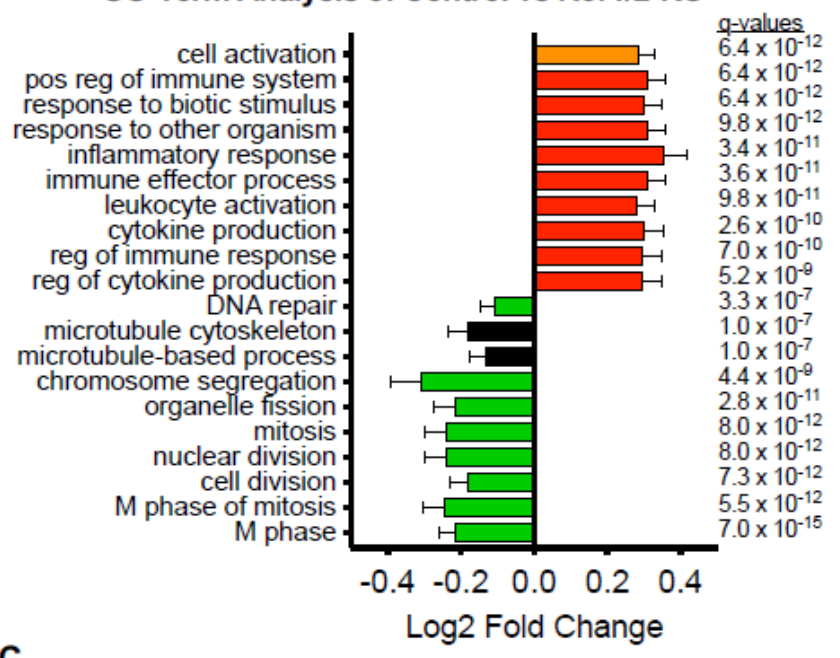

C

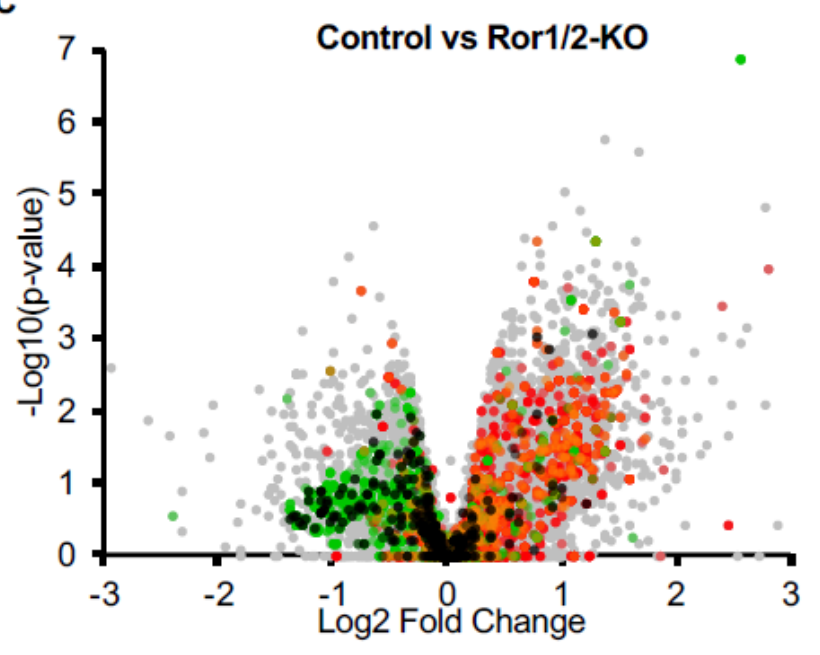

Figure 3. Ror1/2-mediated early fibroblast activation in primary murine cardiac fibroblasts. Primary cardiac fibroblasts were isolated from healthy control and transgenic Ror1/2 double-knockout mice transcriptional phenotype was assessed by bulk RNA sequencing. A) RNA transcript reads of specific genes related to planar cell polarity, inflammatory cytokines, proliferation and cell division, ERK1/2 signaling, matrix remodeling, natriuretic signaling, and myofibroblast differentiation were quantified as normalized Z-score (4 samples for each genotype). B) Gene ontology analysis of differential gene expression between control and Ror1/2-KO cardiac fibroblasts showed the top 10 up-regulated and down-regulated terms by qvalue, with terms grouped by color: cell activation in orange, inflammation in red, proliferation in green, and microtubule regulation in black. C) Significance versus fold change of each gene between control and Ror1/2-KO samples was visualized by volcano plot, with genes in each gene ontology term highlighted in corresponding colors (all other genes in grey). 


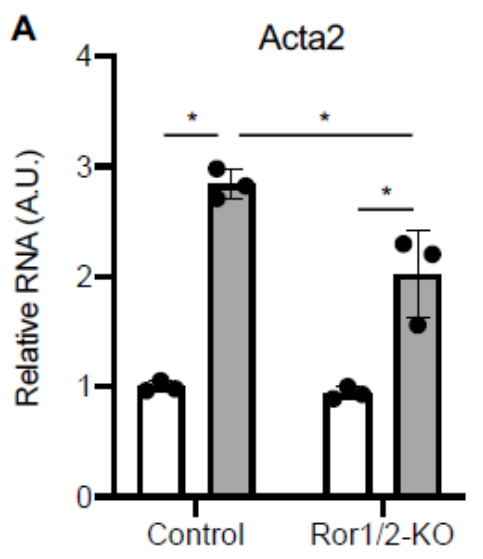

B
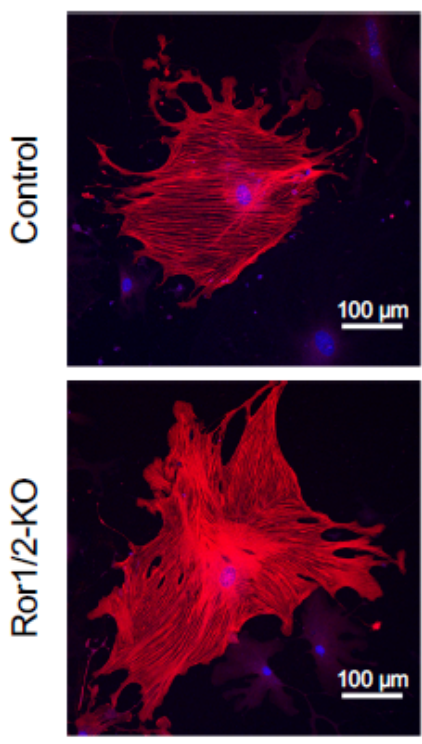

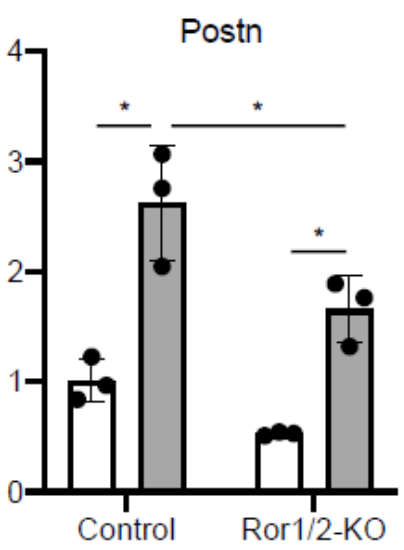

TGF- $\beta 1$ Induction

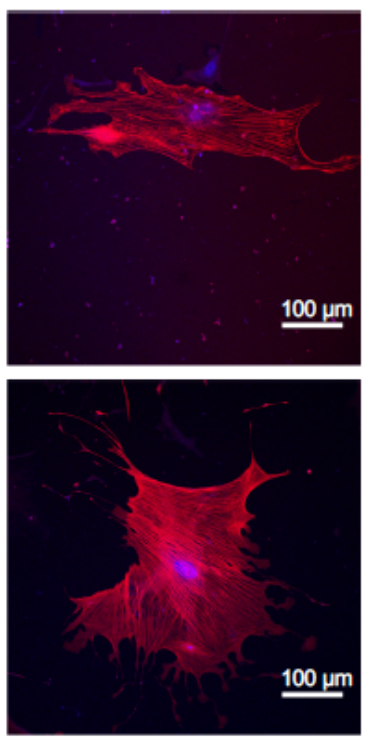

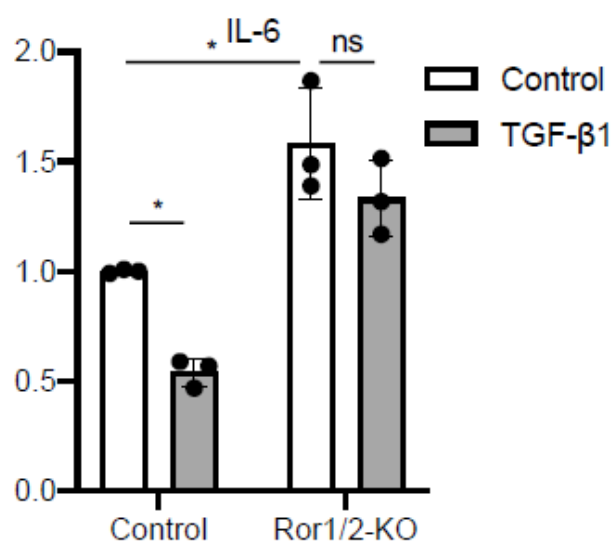

C
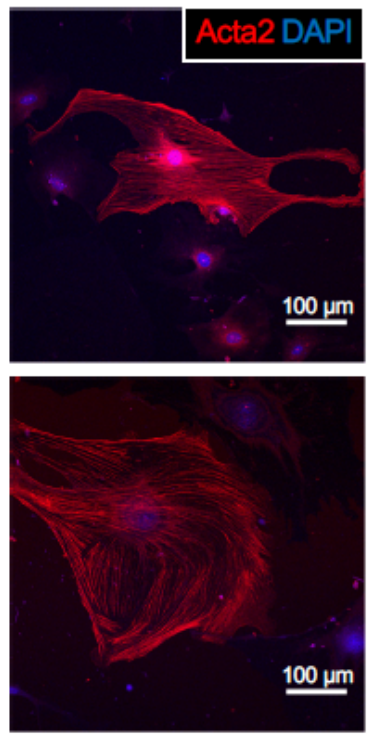

\section{Quantification}

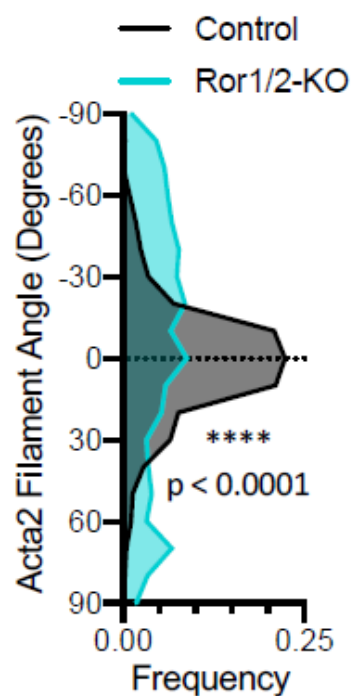

Figure 4. Ror1/2-mediated response to myofibroblast differentiation induced by TGF- $\beta 1$. Myofibroblast differentiation was induced by treatment with $10 \mathrm{ng} / \mathrm{mL}$ TGF- $\beta 1$ for 4 days. A) RNA expression of myofibroblast-related (Acta2 and Postn) and inflammation-related (IL-6) genes was quantified in control and Ror1/2-KO fibroblasts. B) SMa-actin filaments were visualized by immunofluorescent staining of sub-confluent cells in control and Ror1/2-KO fibroblasts, and C) alignment of SMa-actin filaments was quantified and normalized per cell. 


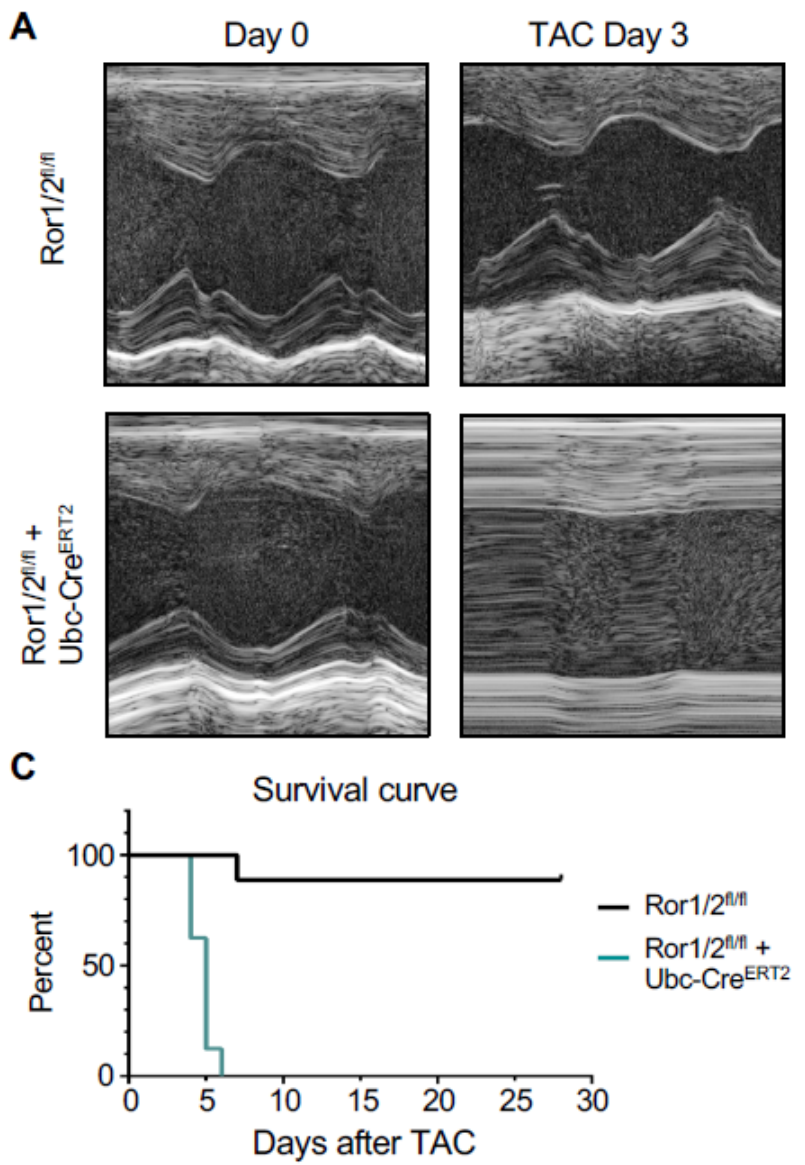

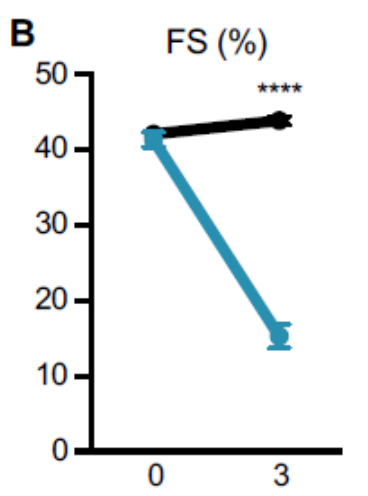

Days after TAC
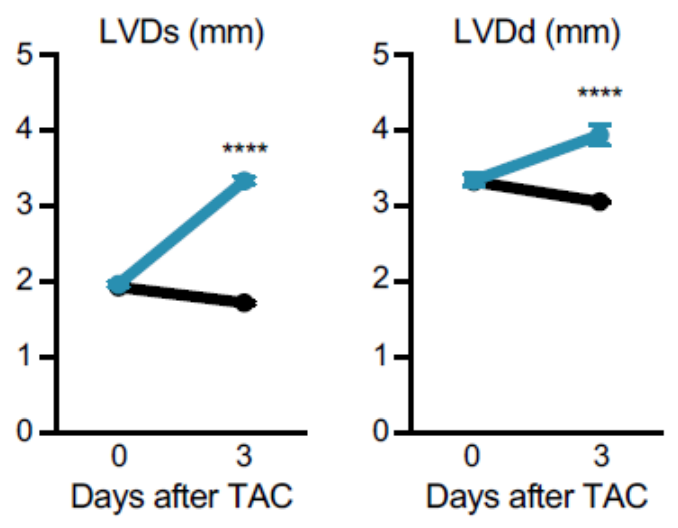

- Ror1/2 $=$ Ror1/1/2

Figure 5. Early heart failure in transgenic Ror1/2 double knockout mice after TAC surgery. A) Transgenic Ror $1 / 2$ double knockout and control mice were subjected to TAC surgery, and cardiac output was imaged by echocardiography. B) Cardiac output factors were quantified: fractional shortening, left ventricular posterior wall thickness at end diastole, left ventricular diameter at end systole, and left ventricular diameter at end diastole. C) Survival of Ror1/2 double knockout mice and control mice after TAC surgery was recorded each day. 


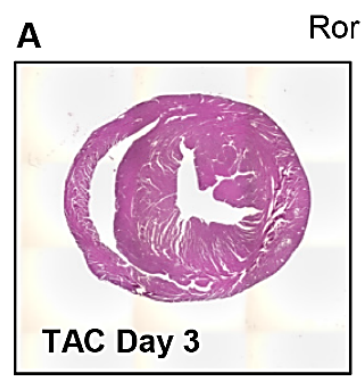

B
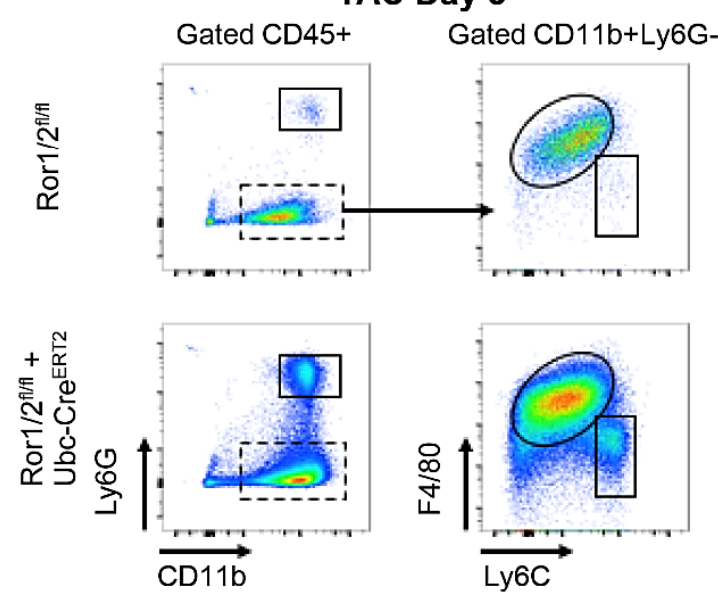

D
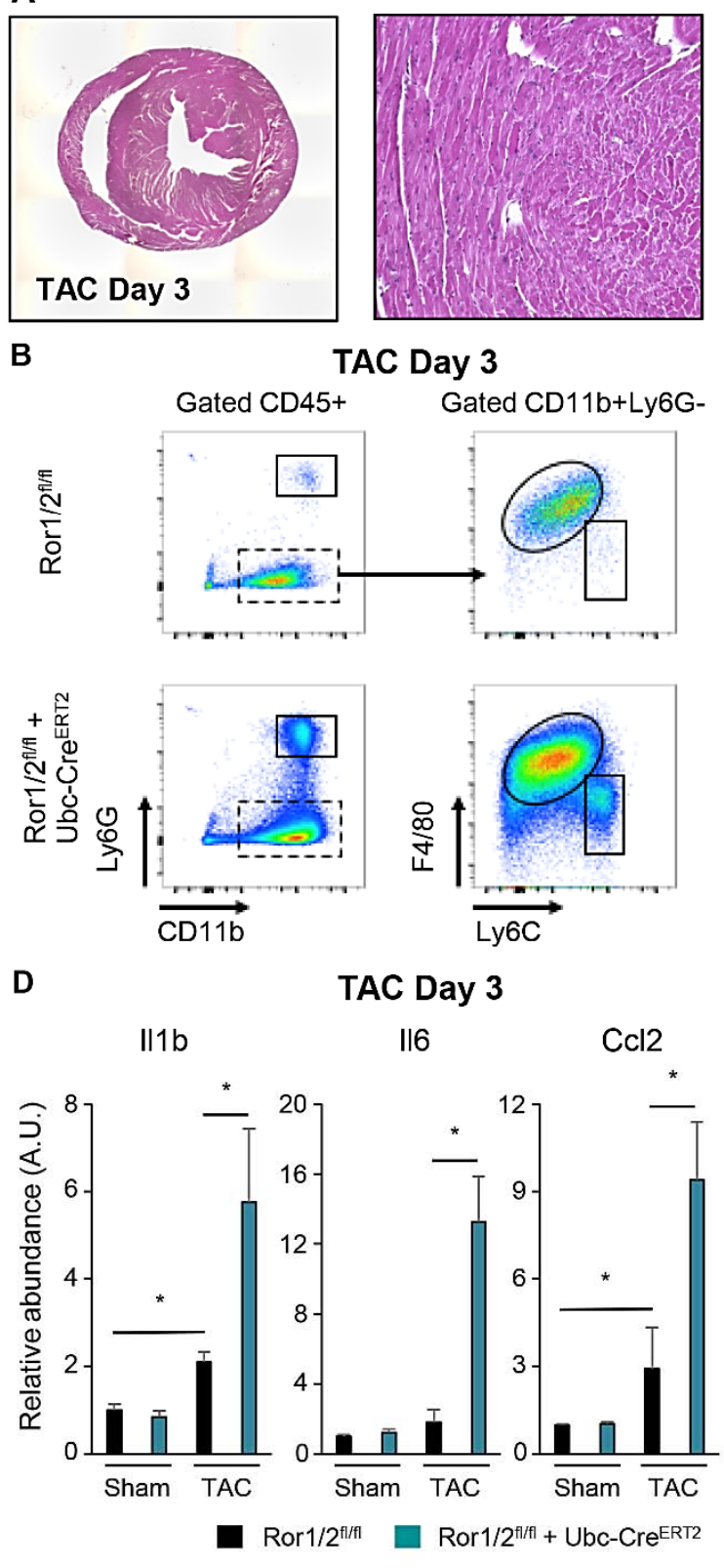

TAC Day 3

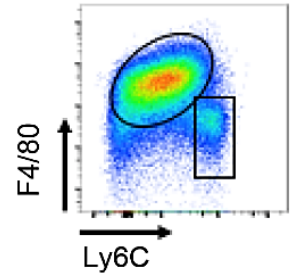

TAC Day 3

116
E

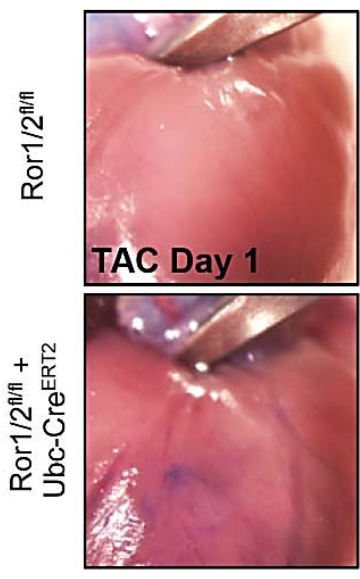

Ror1/2f//f + Ubc-Cre ${ }^{\text {ERT2 }}$
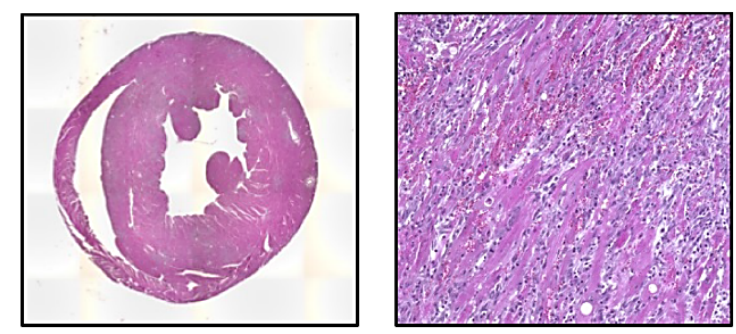

TAC Day 3

Monocyte Macrophage

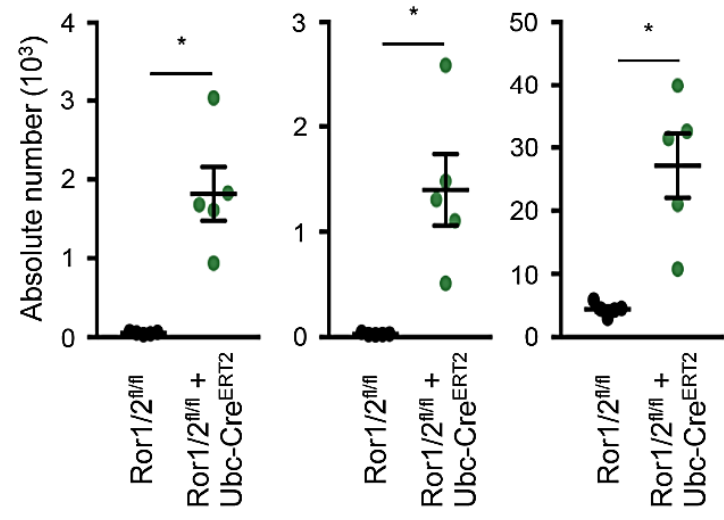

Evans Blue Stain

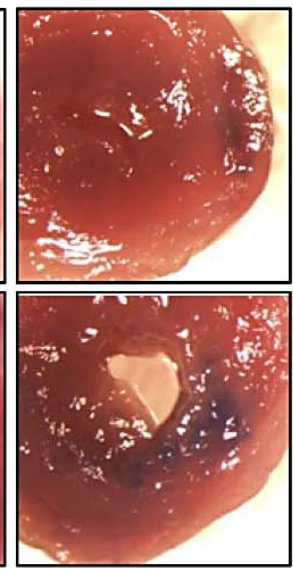

Figure 6. Inflammation response in transgenic Ror1/2 double knockout mice after TAC surgery. Inflammatory profile of control and transgenic Ror1/2 double knockout mice was assessed after TAC or sham surgery. A) H\&E staining of cardiac tissues 3-days post-TAC were imaged. B) Cells were isolated from cardiac tissue and relative quantity of leukocyte populations were determined by flow cytometry, C) quantified by absolute number. D) Gene expression of pro-inflammatory cytokines in cardiac lysate was measured. E) Vascular permeability at 1-day post-TAC was assessed by Evans Blue dye injection, with vascular leakage visualized by blue dye in the cardiac tissue. 